\title{
Military Power and Political Objectives in Armed Interventions
}

\author{
Aaron Rapport \\ Department of Politics and International Studies \\ University of Cambridge \\ ar727@ cam.ac.uk
}

Keywords: Military intervention, policy coercion, territory, military power

\begin{abstract}
What effect do political objectives have on the level of force used in military interventions? Studies have found that states seeking to capture and defend territory are most likely to escalate militarized disputes. However, other research holds that conflicts over policy issues increase uncertainty about an opponent's willingness to resist coercion, obscuring bargains both sides would prefer to fighting. These different findings yield contradictory conclusions about what types of issues should be associated with higher levels of violence. This article contends that the lower levels of force used by states seeking to coerce policy change can be accounted for by the moderating effects of military power. Powerful countries may use low levels of force as a way of gathering information about their opponent's resolve, primarily when the value of this information offsets the costs of screening a target. This will more often be the case in disputes over policy rather than territory, providing an additional reason why such conflicts exhibit lower levels of force. Conversely, weaker powers are less likely to possess the necessary resources to use limited military operations to reduce uncertainty about opponents, and will use similar levels of force regardless of the object of contention. The preceding argument is supported by an analysis of over 175 military interventions carried out from 1945 to 2001.
\end{abstract}


Among militarized conflicts, research consistently finds that territorial disputes exhibit the highest levels of violence (Senese \& Vasquez, 2003, 2008; Vasquez \& Henehan, 2001). State leaders are presumed to attach higher stakes to conflicts over land than other issues, such as those that arise when a state seeks to change the policies or behavior of another actor. However, the latter type of conflicts have been argued to involve higher levels of uncertainty because success depends upon the compliance of the target, making the question of resolve more central to these disputes (Sullivan, 2007, 2012). If uncertainty is a primary cause of war (Fearon, 1995), it would appear disputes over many non-territorial issues should also involve high levels of force. Why then do researchers consistently observe greater levels of violence when land, not policy, is the object of contestation?

This article seeks to connect research on political objectives and conflict with insights provided by strategic bargaining models of war. Bargaining models lead to the expectation that all parties to a territorial conflict will know they share high levels of resolve, which should decrease the uncertainty that contributes to war. However, this does not fit comfortably with the empirical results from behavioral studies of conflict. To resolve this puzzle, I argue that the level of violence associated with different political objectives should depend not only on issue salience and uncertainty, but also on the perceived value and feasibility of using military action to reduce uncertainty. Military action will tend to serve different purposes depending on states' strength and the type of political goals states seek. States in territorial disputes should be less uncertain about the costs of violence, and can sometimes secure their objectives without their opponent acquiescing. Military operations used to secure land are unlikely to be used to screen opponents' for resolve since such information is both more evident beforehand and less relevant to a campaign's success. Conversely, in situations where political goals depend on another actor's 
compliance, states that deploy military personnel are more liable to reduce uncertainty by initially using low levels of force to better estimate their opponent's resolve. If such actions are successful, further military escalation can be avoided, and new beliefs about an opponent may also lead to military withdrawal. This tactic is costly, which is one reason why it is likely to yield an informative response from the target. However, its costliness means that it is a more feasible option for militarily powerful states.

To illustrate, consider the US decision to use a blockade during the Cuban Missile Crisis. US leaders chose a blockade although they doubted it would compel the Soviets to remove their missiles from Cuba (Press, 2005: 130-132). However, they did believe it would reduce uncertainty about Soviet resolve. Attorney General Robert Kennedy and Secretary of State Dean Rusk favored a blockade because it would allow the administration to observe the reaction of both the Soviets and US allies (FRUS, 1996: 131, 133). ${ }^{1}$ President John F Kennedy agreed, saying he wanted to see how the blockade affected the pace of missile deployment in Cuba, which would put the administration in a better position to know what its next move should be (FRUS, 1996: 133). Kennedy thought Soviet compliance with US policy aims was necessary to avert a possible nuclear war, and the US was able to end the crisis without an escalation of force. Alternatively, if officials had been confident they could achieve US objectives via brute force, greater knowledge about Soviet resolve would not have merited the costs of delay they had identified: a blockade allowed the island's defenses more time to mobilize and more missiles to become operational (FRUS, 1996: 129).

This article first reviews theories on how decision-makers with different political objectives formulate assessments of military action. It argues that actors will be more likely to restrain their military operations, using them to screen opponents, when information about

\footnotetext{
${ }^{1}$ FRUS refers to the Foreign Relations of the United States volume on the crisis.
} 
resolve is at a premium. This will be most characteristic of cases in which states try to alter a target's policies or enforce order among its population, as success is more likely to depend on target compliance and thus resolve. However, due to the costs of using military operations to reduce uncertainty, the relationship between political objectives and force levels should depend on the military capacity of the intervening state. This article examines these relationships using data on military interventions conducted from 1945 to 2001.

\section{Stakes, information, and military action}

Multiple bodies of theory purport that territorial conflicts carry higher stakes than other types of disputes (Hensel, 2001: 85). War over land may be one of the oldest human practices (Vazquez, 1993: ch. 4). Narratives about historical homelands can be an important part of nationalist identities, creating a level of psychological investiture that renders certain areas practically indivisible (Hassner, 2009; Toft, 2003). Because territorial claims are particularly salient to domestic publics, leaders may use disputes over land as a platform to consolidate political support while simultaneously making it harder to negotiate with foreign opponents (Huth, 1996). Territorial threats arouse a strong sense of national unity, making them attractive as a casus belli for leaders considering diversionary wars (Tir, 2010).

In contrast to arguments emphasizing territories' subjective value, uncertainty may be less relevant as a cause of military conflict over land. Uncertainty derives primarily from belligerents' private information regarding their destructive capacity and their tolerance for the costs of war, and obscures potential peaceful agreements belligerents mutually prefer to fighting (Fearon, 1995; Powell, 1999). Given the importance normally attached to land, states who assert they are resolved to secure disputed territories should usually be viewed as credible. 
Furthermore, Sullivan $(2007,2012)$ draws from Schelling (1966) to argue that military outcomes in interventions meant to seize territory or overthrow a regime depend largely on destructive capacity rather than cost tolerance. Estimates of resolve are not irrelevant in conflicts over land. However, powerful attackers may sometimes achieve territorial goals using 'brute force' by destroying the target's capacity to resist, making the latter's resolve irrelevant. An opponent's cost tolerance is thus an often important but not always necessary assessment criterion for those seeking to secure land by force.

Conversely, Sullivan observes that military actions meant to alter an opponent's policies or enforce order amongst a population necessitate a target's compliance for success. Destruction of an opponent's material capacity to resist is insufficient for even powerful states to achieve such goals. This makes assessments of a target's will to resist, as opposed to material capacities, more crucial for calculating the costs of combat. Another important source of uncertainty exacerbated in policy disputes stems from whether an opponent will commit to the terms of a settlement. Even after a target has nominally agreed to adjust its policies, its opponent must continue to monitor its behavior to insure compliance (Schultz, 2010). Conversely, once an attacker has seized disputed territory, its opponent's compliance becomes less relevant. Even if the defeated side does not relinquish its territorial claim, leaving the issue unresolved in the longterm, new 'facts on the ground' may severely limit the defeated party's capacity to change the status quo for an indefinite period. This helps explain why seizing strategic ground is an effective war termination technique-it diminishes the need to rely on an opponent's compliance with settlement agreements (Reiter, 2009).

In sum, the increased importance of the intangible, evasive factor of resolve in conflicts over policy heightens uncertainty and makes it more difficult to estimate the costs of securing 
one's objectives (Sullivan, 2007, 2012). The very object of contention is also less tangible when policy rather than land is at issue. Disputed lands are typically more divisible than issues related to policy, status, and prestige (Bercovitch \& Langley, 1993; Colaresi, Rasler \& Thompson, 2007: 79-80; Vasquez, 1983). This means peaceful settlement options may be more obvious to opponents at the outset of conflicts over territory. ${ }^{2}$ Belligerents might see some territories as indivisible, such as those containing religiously sacred spaces. However, research on indivisible territory note that such cases are exceptions to the rule (Hassner, 2003: 12-13). Further, strong actors can still seize indivisible territory using brute force (Hassner, 2003: 24; Goddard, 2006: 38). Thus, even when territory cannot be effectively divided, uncertainty about an opponent's resolve is still less relevant when calculating the costs of military action.

The US invasion of Iraq in 2003 illustrates the relative difficulty of calculating the costs of coercing policy change and maintaining order compared to securing territory and toppling governments. Despite Saddam Hussein's unwillingness to comply with US threats, US forces rapidly seized Iraqi territory and toppled its government by relying on brute strength. Moreover, military estimates of the costs of doing so were largely accurate (Gordon \& Trainor, 2006: 90). However, after Hussein had fallen, the Bush administration's objective became the establishment of a new, democratic government. Unlike taking Baghdad, this goal necessarily required the compliance of Iraqi elites and the maintenance of order within the wider population.

Psychological biases (Lake, 2010/11) and uncertainty over the population's willingness to accept US plans led the administration's cost estimates of the post-Saddam phase of the intervention to be wildly off the mark.

\footnotetext{
${ }^{2}$ Policy disagreements over tangible items still require an intervener to monitor an adversary if physical sites are destroyed. Such strikes may also harden a target's resolve, reducing the like lihood of compliance, as Israel's strike against Iraq's Osirak reactor illus trates.
} 
Another instructive example is France's decision to occupy the Ruhr to coerce Germany into paying reparations after World War I. 17,000 French and Belgian troops quickly seized coal-producing areas, but territorial objectives proved easiest to secure. Getting Germany to comply with France's reparations policies was an entirely different matter. Miners in the Ruhr openly opposed the occupation, and railway workers refused to transport coal for French consumption. By May the number of occupying forces had climbed to 100,000 , and workers had to be imported from abroad to keep German mines producing (Kent, 1989: 211-213). France grossly underestimated the costs of compelling policy change, as well as the challenge of getting Germany to abide by the reparations policy imposed on it after a deal had been reached (Kent, 1989: 241-242).

Military power, political objectives, and screening in interventions

The preceding discussion poses a conundrum. On the one hand, the stakes attached to territorial issues should lead political actors to be more willing to bear the costs of military conflict compared to other types of disputes. On the other hand, uncertainty about resolve and acceptable bargaining solutions should be more problematic for states in conflicts over policy that require a target's compliance. It might seem that high-stakes conflicts over policy would be the most likely to exhibit high levels of violence. States would be willing to use force as in territorial disputes but less able to discern the costs of doing so, making bargaining more difficult. However, this presumption ignores potential avenues for reducing uncertainty-a simpler task than altering a contested issue's salience. Although perceptions of territory's value are not fixed (Goddard, 2006), it is as difficult to change the subjective value of land as it is to change its geographic position, material endowments, or beliefs about its national importance. 
Conversely, avenues by which policymakers may reduce their uncertainty about an opponent's tolerance for costs are more readily available.

At the extreme, states may engage in extensive military operations to learn about an opponent's resolve (Goemans, 2000; Powell, 2004; Wagner, 2000). Alternatively, diplomatic communication can reveal information about an opponent's tolerance for costs without armed conflict taking place (Fearon, 1994b; Powell, 1996). Another method of reducing uncertainty is to use limited military operations concurrently with negotiations to provoke a reaction from one's opponent. Deploying even limited forces near a target's territory increases the chance that an altercation will occur 'accidentally' at a time not of the intervener's choosing (Schelling, 1960). This risk increases the strength of the signal sent to the target, whose reaction may decrease uncertainty more than if it were to respond to diplomatic negotiations alone. States may be able to send costly signals to their target without deploying forces by generating audience costs (Fearon, 1994a; Schultz, 2001), but it is difficult to find evidence for this proposition (Snyder \& Borghard, 2011; Trachtenberg, 2012). By contrast, deploying military forces is inherently costly, and also has a hands-tying effect by increasing the probability a challenger will win an armed conflict (Slantchev, 2005). Still, compared to operations that start with high levels of force, limiting one's initial military actions has the drawback of allowing an opponent to augment its defensive capacity, making the prospect of further escalation more costly. Along with risking ill-timed or accidental escalation, it becomes more difficult to disengage from a conflict than when engaging in diplomacy alone,

The question for belligerents is whether information about their target's resolve is valuable enough to absorb the costs that correspond with limited military operations. The less relevant an opponent's resolve is to securing political objectives, the less bearable these costs 
will appear - they will not be offset by comparable gains in information. States can use brute force to seize land even when uncertainty about an opponent remains, as well as to alleviate concerns about future commitment problems. This is less true when actors' goals depend on their opponents' compliance, and thus one would expect to see the strategy just described more often when states sought to compel policy change or maintain order among an occupied population. Furthermore, the costs of using low-levels of force to gather information are lessened, though not eliminated, for militarily powerful states. Strong states can bring significant resources to bear in a conflict and are more capable than weaker counterparts of overcoming defensive gains that delay might afford an opponent. Limited operations also increase the possible duration of a military intervention, as escalation (if it comes) will be delayed. Long deployments carry fewer opportunity costs for stronger states; a diversion of resources is unlikely to leave them in a position where they cannot seek other objectives. Furthermore, unilateral withdrawal from a military engagement is much more feasible for strong states (Sullivan, 2008: 56). Thus, powerful countries should have more options for managing conflicts over policy, consistent with research indicating that major powers are more effective at managing conflict dynamics generally (Leng, 1993: 101-102).

There is evidence that military power and conflict objectives interact in important ways. Sullivan's (2012: 94-95) analysis of militarized interstate disputes (MIDs) finds that states become less likely to use force in disputes over territory and attempts to overthrow regimes as their power advantages grow. Conversely, military advantages have no effect on the probability that force is used in disputes over policy. It appears that military advantages typically reduce uncertainty over which side would win territorial disputes, increasing the probability of peaceful resolutions. Alternatively, the added uncertainty about the costs of securing an opponent's 
compliance in a policy dispute means that military advantages do not translate into significantly greater confidence about the results of armed conflict. This makes even strong states reluctant to use force. Even if they could use limited military operations to reduce uncertainty, the relatively low stakes typically associated with policy disputes may not merit such costly action. But what of when the stakes in policy disputes are relatively high? Such states will both be motivated and faced with considerable uncertainty. If states in these situations cannot reduce uncertainty about their target's resolve, they are likely to engage in high levels of violence. On the other hand, powerful states in these scenarios should be able to use limited military action to screen an opponent before committing to more intensive operations. When the stakes surrounding a policy issue are great enough to merit the deployment of forces, military power should be effective in reducing uncertainty.

Counter-intuitively then, one might still be less likely to observe high levels of force in military conflicts over policy even when the perceived stakes are great, provided the state deploying forces is sufficiently strong. States using probing actions to gauge an opponent's resolve may choose to escalate to higher levels of force if initial operations do nothing to decrease uncertainty, an altercation compels escalation, or officials come to believe they underestimated the cost of securing their objectives. However, actors might also revise their cost estimates upward sharply enough that withdrawal seems most prudent. They might also persist in applying low levels of force if officials see quick progress towards securing their goals, or come to believe their initial cost estimates were too high, making the application of higher levels of force unnecessary. In sum, underestimating costs may lead either to escalation or withdrawal, whereas overestimating costs should invariably lead states to forgo greater levels of force. If these dynamics are more likely to accompany conflicts over policy, then a greater proportion of 
such conflicts should end before high levels of force are used. Conversely, states that select military action in territorial conflicts—-when brute force can work to secure goals and/or alleviate worries about commitment problems - have fewer incentives to refrain from combat.

\section{Hypotheses}

The discussion to this point yields several hypotheses. First, states whose goals depend on a target's compliance will be less likely to commit to high levels of force against targets than actors whose objectives can be achieved by brute force. Policy coercion and the enforcement of order among a target's population are theorized to more dependent on compliance than territorial objectives or deposing regimes. In the first two types of conflicts, limited operations are most useful for gauging a target's resolve. Although challengers may choose to bring more resources to bear if their initial estimates of the costs of success were too low, they will withdraw at lower levels of force more often than attackers who can use brute force to seize territory or overthrow regimes. The costs of limited military action are unlikely to be offset by greater certainty in these latter types of conflicts, decreasing the probability states will opt for limited operations.

The hypothesis that conflicts over territory exhibit higher levels of force than those over policy is not new. However, the preceding will be contingent on states' military power. Weaker powers may not be able to afford the cost of using limited military operations to reduce their uncertainty about an opponent's tolerance for costs. Having chosen military action, they will be more likely to use high levels of force even if the costs of victory are difficult to discern. Stronger states, alternatively, are more capable of absorbing the monetary and opportunity costs of longer deployments, need be less concerned about the forfeiture of speed and surprise, and can unilaterally withdraw more easily than weaker states. Powerful states are thus more likely to opt 
for limited operations and conclude conflicts without using high levels of force, but only when their goals depend on a target's compliance. When pursuing objectives that can be secured with brute force, powerful and weak states will behave similarly, as the value of screening operations are less likely to outweigh their associated costs.

Hypothesis 1: Stronger military powers are less likely to use high levels of force when they seek to coerce policy change or enforce order than are weaker powers.

Even if states ultimately decide to use high levels of force against a target, they should wait to do so in order to allow initial probing actions enough time to alleviate uncertainty. They should also be more prone to wait to use force - if escalation comes at all - if they perceive they overestimated the costs of securing their goals. Again, differences between strong and weak powers will emerge if the costs of delaying action are higher for the latter types of states.

Hypothesis 2: Stronger military powers are more likely to delay the use of force after deploying military personnel when they seek to coerce policy change or enforce order than are weaker powers.

\section{Research design}

To analyze the preceding hypotheses I use the Military Interventions by Powerful States (MIPS) dataset (Sullivan \& Koch, 2009), which contains 126 interventions by the current permanent members of the United Nations Security Council (UNSC) from 1945 through 2001. Interventions are defined as 'the official deployment of at least 500 regular military personnel (ground, air, or naval) to attain immediate-term political objectives through action against a foreign adversary.' The MIPS dataset differentiates between different types of primary political objectives (PPOs) sought by intervening states. Its smaller size allows for greater specificity on this dimension than does MID data (Sullivan \& Koch, 2009: 708), which only classifies objectives for 'revisionist' states. 57\% of dispute participants in the MID 3.1 dataset (Ghosn, 
Palmer \& Bremer, 2004) are not classified as having any objective, including more than onethird of all dispute initiators.

Using intervention participants as the unit of observation lessens the primary factor confounding the inference that uncertainty drives lower levels of force when powerful states have non-territorial goals: the possibility that political actors also attach significantly less value to such goals. MIPS requires military personnel to be deployed abroad and prepared to use force in each case, whereas the MID database does not require deployments. Since all states in MIPS deployed combat-ready forces abroad regardless of their objectives, the stakes across cases should be expected to be relatively high. Consistent with this conjecture, $88 \%$ of the cases in MIPS escalate beyond a display of force, compared to $71 \%$ of disputes in the MID dataset.

Lastly, if states become engaged in military hostilities during a MID, the measure of force applied is coarse. MID data codes for seven different types of force, but does not rank the intensity of each type relative to the others (Jones, Bremer \& Singer, 1996: 171). The upper end of force levels in MIDs thus jumps from 'force' straight to 'war', and less than 5\% of disputes become wars. By comparison, the MIPS dataset's measure of force is fine-grained. Aside from displays of force in which troops do not engage in combat, interveners may also use limited air and/or naval operations featuring fewer than 500 ground troops and less than 500 target casualties ( $7 \%$ of cases); limited ground commitments with fewer than 2000 ground troops, including military advisors (17\%); extensive uses of air and naval power involving fewer than 2000 ground troops and at least 500 target casualties (9\%); and extensive ground combat operations with more than 2000 ground forces (55\%).

The International Crisis Behavior (ICB) dataset is somewhat suited for testing the hypotheses laid out above. A crisis is defined as a situation in which decision-makers perceive a 
threat to basic values, a finite period of time in which to respond, and a high probability of military hostilities (Brecher \& Wilkenfeld, 2000: 3). As in interventions, the subjective stakes in a crisis are typically greater than in a MID (Jones, Bremer \& Singer, 1996: 167-168). Every crisis participant is categorized according to the predominant issue they believe to be threatened during a crisis, though the issue categories are less precise than in MIPS. For instance, the 'military-security' and 'economic-developmental' categories include numerous cases in which territory is central, but also capture issues related to 'change in the military balance' and economic problems. The 'political-diplomatic' and 'cultural-status' categories roughly correspond to conflicts over policy and 'non-material values' like 'ideology', but also contain concerns such as 'population problems'. Nevertheless, the results found using MIPS closely resemble those when ICB data is used instead (see online appendix).

A shortcoming of MIPS is that it selects cases on the basis of interveners' disproportionate military power, thus truncating variance on this dimension. To address this, I added 47 additional interventions to the MIPS data conducted by states outside the UNSC's permanent membership from 1945 to 2001 . These cases were collected using the ICB dataset, which does not select cases based on actors' military power. Using ICB narratives and secondary sources, I determined whether one or more of the actors in each case from 1945 to 2001 officially deployed at least 500 military personnel against an opponent during a crisis, matching the definition of intervention in MIPS. I then determined whether the crisis interveners pursued one of the six primary political objectives coded for by MIPS, objectives discussed further in the section on explanatory variables. ${ }^{3}$ If so, the crisis intervention was added to the dataset. Analyses of the enlarged dataset return results that are very similar to those in Sullivan

\footnotetext{
${ }^{3}$ The secondary sources used to code cases are too numerous to list here. Compilations of these sources, listed alphabetically and by case, are available on request.
} 
(2007: 514), indicating that little damage is done to unit homogeneity by adding the cases from ICB (see online appendix). Analyses were conducted using both the original set of cases and the enlarged dataset to examine whether results differed substantially between the two.

\section{Dependent variables}

The dependent variable used to test the first hypothesis is force level, the most extensive use of force an intervener engaged in during an intervention. The most common force level in both the original and enlarged datasets was extensive ground combat, constituting 54\% and 63\% of the observations, respectively. $13 \%$ of the observations in the enlarged dataset did not escalate beyond a display of force, compared to $12 \%$ in the original MIPS data.

The dependent variable for the second hypothesis is escalation delay. This variable is coded as 1 if states did not use force against a target on the first day of a military intervention, and 0 otherwise. The ICB data provides detailed descriptions of the major events in a crisis, making the task of determining the number of days from the start date of each interventionwhen military forces entered the territory or waters of the target - until the first use of force fairly straightforward for some cases. For the majority of observations in the data, the date of the first military action beyond a display of force was also ascertained using a combination of secondary literature and news summaries such as Keesing's Contemporary Archives. Interveners applied force on the first day in $73 \%$ of the cases. 24 of the interveners in the remaining cases eventually applied force against a target, while 23 never escalated beyond a display of force.

\section{Explanatory variables}

The first explanatory variable used to test the preceding hypotheses is the intervening 
state's primary political objective (PPO). MIPS and ICB data contain detailed descriptions of the intervening state's political objectives; numerous secondary sources were also used to clarify any ambiguity about interveners' military goals (see footnote 2). MIPS codes the PPO of each intervention as the main 'concrete, observable, immed iate-term outcome to be attained through the employment of military force' (Sullivan \& Koch, 2009: 710). There are six PPOs in the data: acquire or defend territory; remove a foreign regime; maintain a foreign regime; maintain control of empire; enforce peace and order; or compel policy change by a targeted state. The last two objectives are most dependent on the compliance of the target and theorized to entail the most uncertainty over costs. Following Sullivan $(2007,2012)$ they are combined into a single dichotomous variable compliance PPO. Brief descriptions of each of the 35 interventions with a compliance PPO may be found listed in chronological order in the online appendix. Likewise, the maintenance of imperial and foreign regimes are grouped into the single nominal category moderately coercive PPO. Territorial objectives and regime change, theorized to be least dependent on target compliance, are used as the base category. If an intervener adopts a new objective during the course of a military intervention, MIPS treats that phase of the campaign as a new case. For example, China's entry into the Korean War in October 1950 is coded as having the purpose of defending territory in North Korea. By December 1950 a new case is created in which China's PPO is coded as the removal of Syngman Rhee's regime.

The other key explanatory variable is the intervener's military power. This was measured using the Composite Index of National Capabilities, or CINC (Singer, 1987). CINC scores capture a state's share of all countries' material capabilities held in a given year and fall between 0 and 1 . This variable was included in interaction with the compliance PPO variable to test hypotheses one and two. 


\section{Control variables}

Numerous variables may confound the relationship between PPOs and force level. While the problem of controlling for the stakes attached to different issues is partly dealt with by using interventions as the unit of analysis, relative resolve is meant to capture the salience of the issues at stake to both the intervening state and its target. It follows the coding scheme set out by Sullivan (2012: 87), in which there are five ordinal categories of issue salience. In ascending order, these are missions to change an adversary's policies; maintain one's own domestic or foreign policies; gain territory, maintain imperial holdings or defend an ally; defend territorial integrity or remove an adversarial regime from power; and defend one's sovereignty and/or governing authority. The salience of the issues at stake in an intervention was coded using the MIPS and ICB data as well as secondary sources on international conflict. If the salience of the issues at stake was equal for both parties, or higher for the intervener than the target, relative resolve was coded as 1 , and 0 otherwise. Targets were coded as having higher resolve based on the issues at stake in $72 \%$ of the cases in the enlarged dataset, a proportion virtually identical to that in the original MIPS data (Sullivan, 2012: 110).

It is necessary to measure relative resolve rather than that of the intervener and target separately for several reasons. First, using a separate measure of intervener resolve creates high levels of collinearity with PPO types, particularly a strong negative correlation between compliance PPOs and issue salience. This makes the individual effects of issue salience and uncertainty on force levels difficult to parse. Second, it is important to consider whether the balance of interests in a conflict is uneven (Mack, 1975). If an intervener with a military advantage has the additional advantage of having equal or greater cost tolerance, there will be less uncertainty about its willingness to engage in intense combat to achieve its aims. Its target 
should be apt to concede quickly, precluding the need for extensive combat operations. However, in most cases the weaker target in an intervention has more at stake than their opponent. This partially offsets the intervener's military advantage and increases uncertainty about conflict outcomes, perhaps subsuming any uncertainty arising from the nature of the intervener's PPO.

The second variable used to measure issue salience is whether or not the intervener was a crisis actor. This dummy variable is coded according to ICB data. An intervener may not be a crisis actor even if their actions trigger a crisis for their target. The heightened sense of time pressure during a crisis should increase the perceived value of the issues at stake as well as strengthen beliefs that armed conflict is likely (Brecher \& Wilkenfeld, 2000: 4). This may overwhelm actor uncertainty as a reason to limit operations or delay escalation during an intervention. The crisis actor variable has only a modest relationship with relative resolve $(\varphi$ coefficient $=0.12$ ).

The second set of control variables relate to the balance of forces in a given conflict, which in turn is related to the certainty with which states can assess the costs of fighting. The relative military capabilities of an intervener and its target is constructed by dividing the CINC score of the intervener by that of its target and logging the resulting ratio, as there should be diminishing returns to power advantages. CINC scores for both states prior to the year of intervention are used to eliminate the possibility that the conflict impacts the measure. Relative military capabilities range from -1.71 to 10.26 (mean $=5.03, \mathrm{sd}=3.54)$. This variable correlates moderately with intervener's military power (0.20), and is included for several reasons. First, even very powerful states may be wary to use extensive military operations against a similarly strong opponent. The potential for massive retaliation by the USSR is a good explanation for the 
US decision to forgo immediate airstrikes in Cuba, though uncertainty about Soviet resolve mattered as well. The greater difficulty of unilateral withdrawal in cases of power parity exacerbates the risks of deploying forces, although this might also present a rationale for striking hard and fast rather than probing an opponent with limited operations. Second, smaller relative advantages should increase the amount of uncertainty regarding which side would emerge victorious in an armed conflict and arguably increase the likelihood of military escalation between dyads (Organski \& Kugler, 1980; Kugler \& Lemke, 1996). It could be argued that militarily powerful states use lower levels of force during interventions not because of the uncertainty associated with certain PPOs, but rather because power disparities lead their targets to yield early in a conflict.

One factor complicating the construction of the relative military capabilities variable is that half of the cases in MIPS and $44 \%$ of cases in the enlarged dataset feature non-state targets without CINC scores. Sullivan (2012: 109) compensates by assigning the CINC score of the weakest state in the international system in the year of a given intervention to non-state targets. Similarly, I assign non-state targets the CINC score of the weakest state in the dataset: Grenada, the target of a US military intervention in 1983 , had a $0.001 \%$ share of the international system's material capabilities the year prior. Partially due to this complication, analyses also control for whether or not the target is a state. Theoretically, the character of 'conventional' warfare is substantively different from military operations targeting non-state actors: the latter activities often involve more uncertainty for state actors, particularly in an era of mechanized warfare (Arreguin-Toft, 2001; Lyall \& Wilson, 2009).

Another dummy variable related to power differences controls for whether or not the intervener was accompanied by a coalition of states from outside the targeted territory. This 
variable captures the effects of states with lesser CINC scores on the most powerful intervener's effort. Intervening in a coalition may be considerably less efficient than engaging in operations unilaterally (Weitsman, 2014), and may thus delay the decision to use force after personnel are deployed. A dummy variable coding for instances in which other states committed military personnel in a combat or advisory role troops to assist the intervention target—-target assistance - also is included. An intervening state may be aware that its target is receiving assistance in the form of military equipment and/or technical advice, but uncertain of the extent of such outside involvement. Besides affecting the balance of forces in a conflict, such assistance might complicate an intervener's assessments of the costs of escalation and possibly convince an intervener to withdraw from a dispute before it escalates. Having a local ally can also significantly impact the probability that an intervener successfully achieves its aims due to the ally's ability to provide forces and absorb costs (Sullivan, 2007). If they are willing and able to fight, local allies may allow interveners to commit to lower levels of force or delay escalation. The presence of a local ally or target assistance was ascertained using the MIPS and ICB data, as well as secondary sources on individual conflicts.

Analyses also included a variable for whether or not an intervening state was a democracy. The openness of political debate and competition in democratic regimes may allow them to more effectively signal their intent and resolve (though see Downes \& Sechser, 2012), perhaps leading targets to concede to democratic states' demands before a conflict escalates to high levels of violence. Huth \& Allee (2002) also find that democracies' political accountability can account for decisions to negotiate concessions in the early stages of territorial disputes. The constraints on executive action in democracies may make them slower to apply force even after military personnel are deployed. Conversely, once democracies do decide to engage in military 
conflict, the greater political accountability of leaders may cause them to expend more effort and use higher levels of force than non-democratic states (Bueno de Mesquita et al., 1999). If an intervener's democracy score minus its autocracy score in the Polity IV dataset (Marshall \& Jaggers, 2007) was greater than or equal to 7, it was coded as a democracy.

\section{Results}

To evaluate the first hypothesis I ran a series of ordered logistic regression models on the dependent variable force level. The first models included the control variables and then added the main explanatory variables in iterations to view the main and interaction effects. Model 3.1 reflects earlier findings that territorial objectives are associated with higher levels of force. The coefficient for compliance $P P O$ is in the expected negative direction and achieves statistical significance, indicating that intervening states were less likely to use higher levels of force when they sought territorial objectives, even controlling for crises and the relative resolve of intervener and target. This result also held when the model was run using only the original cases in the MIPS data (coefficient $-1.966, p<0.05$ ). However, when compliance PPOs interacts with intervener military power in Model 4.1, the main effect of the former variable loses statistical significance. Alternatively, the interaction term is significant and in the expected direction, consistent with the first hypothesis that stronger military powers are less likely to commit to high levels of force when their goals necessitate their target's compliance. Substantively similar results are obtained using the ICB data (see online appendix).

TABLE I IN HERE 
Unsurprisingly, when Model 4.1 was run using only the original MIPS cases, the sign of the interaction coefficient was in the expected direction but could not be significantly differentiated from zero (coefficient $-16.730, p=0.105$ ), likely because of the more limited variance in intervener military power. However, the interaction term in Model 4.1 retains significance even after dropping the 37 weakest interveners from outside the original MIPS data, or almost $80 \%$ of the new cases (coefficient $-18.786, p<0.05$ ). This leaves only states at least as strong as Vietnam in 1978 in the analysis. The interaction term in the model also retains significance if the 11 interveners whose primary objective was to enforce peace and order are dropped from the analysis (coefficient $-16.454, p<0.01$ ). However, dropping the 24 interventions meant to compel policy change actually flips the sign of interaction term and leaves the effect statistically insignificant (coefficient $6.342, p=0.651$ ), indicating that interveners with policy rather than order PPOs are driving the results.

The different intervention behavior between strong and weak interveners is shown graphically in Figure 1, which displays the probability that a state engages in increasing levels of force against its target. To create the figure, the values of the control variables in Model 4.1 were set to their means or modes. The estimates for 'Strong Interveners' were generated by setting intervener military power to the $75^{\text {th }}$ percentile for states in the dataset -0.139 , or $13.9 \%$ of the world's total military capacities in a given year. Alternatively, the 'Weak Intervener' estimates were generated by setting intervener military power to the $25^{\text {th }}$ percentile, or 0.018 . There is no significant difference between strong and weak powers in the middle range of the force level variable. Conversely, significant differences between strong and weak states with compliance PPOs emerge at the extreme ends of the force spectrum. Strong interveners are roughly five times as likely to engage in no more than a display of force, a 35 percentage-point 
shift. At the other end of the spectrum, weak powers were almost four times more likely to engage in ground combat operations, a 46 percentage-point difference. This supports the argument that strong interveners can afford to use low-intensity operations to gauge a target's resolve. Even controlling for crises and relative resolve, they appear unlikely to escalate beyond a display of force when their goals require a target's compliance. Weaker states, on the other hand, are less able or willing to select such a strategy when pursuing compliance PPOs.

\section{FIGURE 1 IN HERE}

Conversely, there are no substantial differences in the amount of force used by strong and weak powers in interventions when they pursue territorial or regime-change PPOs. Likewise, one may use compliance PPO as the base category in Model 4.1 and group territorial and regime removal PPOs into a single category; interacting this 'brute PPO' variable with intervener military power yields a statistically insignificant coefficient $(4.601, p=0.391)$. This supports the argument that it is less useful to employ low levels of force to gather information in interventions whose goals may be accomplished via brute force. Military power does not moderate behavior in these cases, as the benefits gained from limited probing operations are comparatively small and likely to be offset by the costs of such a strategy. It also appears that the force levels chosen by weaker powers do not depend on PPO. In Table II, the estimated differences between the amount of force weaker powers use in compliance PPOs and other types cannot be differentiated from zero. Although weaker interveners are estimated to be 16 percentage points less likely to engage in extensive ground combat when compliance PPOs are at stake, the confidence interval for this difference ranges from a 45 percentage-point decrease to a 12 percentage-point increase. 
Alternatively, the confidence intervals for stronger powers in Table III overlap with zero for only two force levels; the amount of force strong interveners use is moderated by PPO as indicated in Model 4.1 and expected by the theory.

\section{TABLES II \& III IN HERE}

Shifting dependent variables to escalation delay, the second hypothesis that powerful states are more likely to delay the use of force when their goals necessitate their target's compliance was supported. The coefficient for compliance PPO in the logistic regression in Table IV (Model 1.2) is consistent with simple observed frequencies: states refrained from using force on the first day of an intervention in 16 out of the 35 cases $(46 \%)$ in which objectives were most dependent on a target's compliance. This was so only $22 \%$ of the time when states sought other types of objectives. However, the interaction term in Model 2.2 shows that the effect of compliance $P P O$ is contingent on an intervener's military power. Stronger states are more likely to delay the use of force than are their weaker counterparts irrespective of political objectives, but especially when success requires target compliance. This is consistent with the argument that stronger powers are more able to afford the costs of delay when forces have been deployed and potential military hostilities are afoot, and that they will find delay more advantageous depending on uncertainty levels. The interaction term still retains conventional levels of significance after excluding the 16 weakest interveners added from the ICB dataset.

\section{TABLE IV \& V IN HERE}


It should be cautioned that Model 2.2 is sensitive to how the dependent variable escalation delay is defined. The interaction term's coefficient retained conventional levels of significance if the minimum delay period necessary for escalation delay to be coded as 1 was extended from one to two, three, or four days, as shown in Figure 2. However, if the delay period is extended beyond that the interaction term does not attain significance, as is the case in Model 4.2; the lower bound of the coefficient's confidence intervals cross zero. This is concerning if it seems implausible that a period of one to four days is too brief a period of time for interveners to gauge their target's reaction and update their beliefs about the costs of military action. Further, similar results were not obtained using the ICB data: whether or not states delayed their response to a crisis trigger did not depend on the issues at stake or states' military power (see online appendix). Thus, support for hypothesis two is less robust than that for hypothesis one. The average intervener military power score is almost identical in cases of escalation delay regardless of whether the latter variable is operationalized as a delay of at least one day or greater than four days. Likewise, the number of cases in which there was an escalation delay and the intervener had a compliance PPO declines by only one, from 16 to 15 . The correlation between the interaction term and intervener military power is also not significantly changed in cases of escalation delay between different operationalizations. However, extending the delay period beyond four days reduces the number of cases where escalation delay is coded as 1 from 47 to 41 , or by roughly $13 \%{ }^{4}$ By comparison, extending the delay period beyond three days eliminates only three cases, and beyond one day only one case.

\footnotetext{
${ }^{4}$ Aside from being clustered near the early part of the postwarera, the recoded cases do not appear to be strongly related: Britain's intervention during the Indonesian insurgency (1945); French efforts to reclaim Indochina and Laos (1946); Russia's Berlin blockade (1948) and response to the Poznan Riots (1956); and the US blockade of Cuba (1962).
} 
This may be increasing uncertainty regarding the relationship between military power, intervention objectives, and escalation delay.

\section{FIGURE 2 IN HERE}

\section{Discussion}

Bargaining theories have stressed uncertainty more than issue salience as a cause of armed conflict. However, empirical studies have oft attributed the high levels of violence associated with conflicts over territory rather than policy disagreements to the greater salience of the former issue. Theory and empirics thus do not comfortably fit together. This article helps to resolve this puzzle. Following Sullivan $(2007,2012)$, it demonstrates how the relevance of information about an opponent's resolve varies by issue type, which in combination with considerations of military power can explain the amount of force states apply in interventions. Powerful states can use limited military operations, especially shows of force, to induce reactions from targets which provide information about their opponent's cost-tolerance. This strategy is most attractive when an actor's goals depend on their target's compliance, as with policy coercion. Limited operations are not cost free, however, and their costs are less likely to be borne by weaker states for which there are greater drawbacks that offset the benefits of screening opponents. Furthermore, in territorial disputes, an opponent's resolve tends to be both more obvious and less relevant for military actors, especially when brute force can make an opponent's future commitment to honor territorial boundaries moot. Thus, military power is unlikely to moderate state behavior in such conflicts: strong and weak states should behave similarly. The higher levels of violence associated with territory are attributable less to issue salience than variance in the behavior of great powers seeking to coerce policy change. 
Several implications emerge from these findings. First, uncertainty about an opponent's tolerance for costs may hinder peaceful bargaining outcomes, but it likely also encourages strong actors to be more restrained when engaging in military operations than they would be otherwise. For militarily powerful states, cases in which actors seek to coerce policy change may still feature lower hostility levels than similarly salient conflicts related to territory. This reinforces Sullivan's finding that policymakers in strong states rein in their confidence according to issue type, and complicates existing arguments about the role uncertainty and issue salience play as causes of war. Second, military weakness may invite violence not only because it leaves states vulnerable to attack, as realists have suggested, but also because it hinders the flexibility of weaker states who commit to military action. Policy disagreements such as that over Iran's nuclear program may be likely to dissolve into violent disagreements due to actions taken by weaker regional powers rather than the US. Not only may states like Israel feel more threatened, but their relatively limited capabilities would hinder gradual escalation if military action was taken. Lastly, while monitoring mechanisms are crucial for reducing the likelihood of violence over issues that require actors to abide by settlements (Schultz, 2010), the evidence here indicates this is particularly important in conflicts between militarily weaker states who have fewer avenues for reducing uncertainty.

Data replication: The dataset, codebook, and do-files for the empirical analysis in this article can be found at http://www.prio.no/jpr/datasets.

\section{Acknowledgments}

I would like to thank John Duffield, Stephen Gent, Patrick Johnston, Ron Krebs, Stefano Recchia, Gulcan Saglam, Lauren Wilcox, and the $J P R$ reviewers and editors. 


\section{References}

Arreguin-Toft, Ivan (2001) How the weak win wars: A theory of asymmetric conflict. International Security 26(1): 93-128.

Bercovich, Jacob \& Jeffrey Langley (1993) The nature of dispute and the effectiveness of international mediation. Journal of Conflict Resolution 37(4): 670-691.

Brecher, Michael \& Jonathan Wilkenfeld (2000) A Study of Crisis. Ann Arbor, MI: University of Michigan Press.

Bueno de Mesquita, Bruce; James D Morrow, Randolph M Siverson \& Alastair Smith (1999) An institutional explanation of the democratic peace. American Political Science Review 93(4): 791-807.

Colaresi, Michael P; Karen Rasler \& William R Thompson (2007) Strategic Rivalries in World Politics: Position, Space, and Conflict Escalation. New York: Cambridge University Press.

Downes, Alexander B \& Todd S Sechser (2012) The illusion of democratic credibility. International Organization 66(3): 457-489.

Fearon, James D (1994a) Domestic political audiences and the escalation of international disputes. American Political Science Review 88(3): 577-592.

Fearon, James D (1994b) Signaling versus the balance of power and interests. Journal of Conflict Resolution 38(2): 236-269.

Fearon, James D (1995) Rationalist explanations for war. International Organization 49(3): $379-414$. 
Keefer, Edward C; Charles S Sampson \& Louis J Smith (eds) (1996) Foreign Relations of the United States, 1961-1963, Volume XI: Cuban Missile Crisis and Aftermath (FRUS). Washington, DC: United States Government Printing Office.

Ghosn, Faten; Glenn Palmer \& Stuart Bremer (2004) The MID3 data set, 1993-2001: Procedures, coding rules, and description. Conflict Management and Peace Science 21(2): 133-154.

Goemans, Hein E (2000) War and Punishment: The Causes of War Termination and the First World War. Princeton, NJ: Princeton University Press.

Goddard, Stacie E (2006) Uncommon ground: Indivisible territory and the politics of legitimacy. International Organization 60(1): 35-68.

Gordon, Michael R \& Bernard E Trainor (2006) Cobra II: The Inside Story of the Invasion and Occupation of Iraq. New York: Pantheon.

Hassner, Ron E (2003) To halve and to hold: Conflicts over sacred space and the problem of indivisibility. Security Studies 12(4): 1-33.

Hassner, Ron E (2009) War on Sacred Grounds. Ithaca, NY: Cornell University Press.

Hensel, Paul R (2001) Contentious issues and world politics: The management of territorial claims in the Americas, 1816-1992. International Studies Quarterly 45(1): 81-109.

Huth, Paul K (1996) Standing Your Ground: Territorial Disputes and International Conflict. Ann Arbor, MI: Michigan University Press.

Huth, Paul K \& Todd L Allee (2002) The Democratic Peace and Territorial Conflict in the Twentieth Century. New York: Cambridge University Press.

Kent, Bruce (1989) The Spoils of War: The Politics, Economics, and Diplomacy of Reparations, 1918-1932. New York: Oxford University Press. 
Kugler, Jacek \& Douglas Lemke (eds) (1996) Parity and War: Evaluations and Extensions of the War Ledger. Ann Arbor, MI: University of Michigan Press.

Lake, David A (2010/11) Two cheers for bargaining theory: Assessing rationalist explanations of the Iraq War. International Security 35(3): 7-52.

Leng, Russell J (1993) Interstate Crisis Behavior, 1816-1980: Realism versus Reciprocity. Cambridge: Cambridge University Press.

Lyall, Jason \& Isaiah Wilson III (2009) Rage against the machines: Explaining outcomes in counterinsurgency wars. International Organization 63(1): 67-106.

Marshall, Monty G \& Keith Jaggers (2007) Polity IV Project version p4v2007 (http://www.systemicpeace.org/inscr/inscr.htm).

Mack, Andrew (1975) Why big nations lose small wars: The politics of asymmetric conflict. World Politics 27(2): 175-200.

Maoz, Zeev (1983) Resolve, capabilities, and the outcomes of interstate disputes, 1816-1976. Journal of Conflict Resolution 27(2): 195-229.

Organski, AFK \& Jacek Kugler (1980) The War Ledger. Chicago: University of Chicago Press.

Powell, Robert (1996) Uncertainty, shifting power, and appeasement. American Political Science Review 90(4): 749-764.

Powell, Robert (1999) In the Shadow of Power: States and Strategies in International Politics. Princeton, NJ: Princeton University Press.

Powell, Robert (2004) Bargaining and learning while fighting. American Journal of Political Science 48(2): 344-361.

Press, Daryl G (2005) Calculating Credibility: How Leaders Assess Military Threats. Ithaca, NY: Cornell University Press. 
Reiter, Dan (2009) How Wars End. Princeton, NJ: Princeton University Press.

Schelling, Thomas C (1960) The Strategy of Conflict. Cambridge, MA: Harvard University Press.

Schelling, Thomas C (1966) Arms and Influence. New Haven, CT: Yale University Press.

Schultz, Kenneth A (2001) Democracy and Coercive Diplomacy. New York: Cambridge University Press.

Schultz, Kenneth A (2010) The enforcement problem in coercive bargaining: Interstate conflict over rebel support in civil wars. International Organization 64(2): 281-312.

Senese, Paul D \& John A Vasquez (2003) A unified explanation of territorial conflict: Testing the impact of sampling bias, 1919-1992. International Studies Quarterly 47(2): 275-298.

Senese, Paul D \& John A Vasquez (2008) The Steps to War: An Empirical Study. Princeton, NJ: Princeton University Press.

Singer, J David (1987) Reconstructing the Correlates of War dataset on material capabilities of states, 1816-1985. International Interactions 14(2): 115-132.

Slantchev, Branislav L (2005) Military coercion in interstate crises. American Political Science Review 99(4): 533-547.

Snyder, Jack \& Erica D Borghard (2011) The cost of empty threats: A penny, not a pound. American Political Science Review 105(3): 437-456.

Sullivan, Patricia L (2007) War aims and war outcomes: Why powerful states lose limited wars. Journal of Conflict Resolution 51(3): 496-524.

Sullivan, Patricia L (2008) At what price victory? The effects of uncertainty on military intervention duration and outcome. Conflict Management and Peace Science 25(1): 4966. 
Sullivan, Patricia L (2012) Who Wins? Predicting Strategic Success and Failure in Armed Conflict. New York: Oxford University Press.

Sullivan, Patricia L \& Michael Koch (2009) Military interventions by powerful states, 19452003. Journal of Peace Research 46(5): 707-718.

Tir, Jaroslav (2010) Territorial diversion: Diversionary theory of war and territorial conflict. Journal of Politics 72(2): 413-425.

Toft, Monica Duffy (2003) The Geography of Ethnic Violence: Identity, Interests, and the Indivisibility of Territory. Princeton, NJ: Princeton University Press.

Trachtenberg, Marc (2012) Audience costs: An historical analysis. Security Studies 21(1): 3-42. Vasquez, John A \& Marie T Henehan (2001) Territorial disputes and the probability of war, 1816-1992. Journal of Peace Research 38(2): 123-138.

Vasquez, John A (1983) The tangibility of issues and global conflict: A test of Rosenau's issue area typology. Journal of Peace Research 20(2): 179-192.

Vasquez, John A (1993) The War Puzzle. New York: Cambridge University Press.

Wagner, R Harrison (2000) Bargaining and war. American Journal of Political Science 44(3): 469-484.

Weitsman, Patricia A (2014) Waging War: Alliances, Coalitions, and Institutions of Interstate Violence. Stanford, CA: Stanford University Press.

AARON RAPPORT, b. 1980, PhD in Political Science (University of Minnesota, Twin Cities, 2010); Lecturer, Department of Politics and International Studies, University of Cambridge $(2013-)$. 
Table I. Factors related to force levels

\begin{tabular}{|c|c|c|c|c|}
\hline DV: Force Level & Model 1.1 & Model 2.1 & Model 3.1 & Model 4.1 \\
\hline $\begin{array}{l}\text { Intervener } \\
\text { military power }\end{array}$ & $\begin{array}{c}-7.937 * * \\
(2.739)\end{array}$ & $\begin{array}{c}-9.027 * * * * \\
(2.643)\end{array}$ & $\begin{array}{l}-7.991 * * \\
(2.697)\end{array}$ & $\begin{array}{l}-5.639 \dagger \\
(2.907)\end{array}$ \\
\hline Coalition & $\begin{array}{l}1.064^{*} \\
(0.450)\end{array}$ & $\begin{array}{l}1.039^{*} \\
(0.479)\end{array}$ & $\begin{array}{l}1.094^{*} \\
(0.494)\end{array}$ & $\begin{array}{l}1.260^{*} \\
(0.507)\end{array}$ \\
\hline $\begin{array}{l}\text { Intervener } \\
\text { democracy }\end{array}$ & $\begin{array}{c}-1.286^{* * * *} \\
(0.400)\end{array}$ & $\begin{array}{c}-1.286^{* *} \\
(0.406)\end{array}$ & $\begin{array}{l}-0.975^{*} \\
(0.448)\end{array}$ & $\begin{array}{l}-1.032 * \\
(0.453)\end{array}$ \\
\hline Local ally & $\begin{array}{c}-0.938^{*} \\
(0.402)\end{array}$ & $\begin{array}{c}-0.960^{*} \\
(.383)\end{array}$ & $\begin{array}{l}-1.260^{*} \\
(0.496)\end{array}$ & $\begin{array}{c}-1.362 * * \\
(0.516)\end{array}$ \\
\hline $\begin{array}{l}\text { Military } \\
\text { assistance to } \\
\text { target }\end{array}$ & $\begin{array}{l}-0.319 \\
(0.435)\end{array}$ & $\begin{array}{l}-0.279 \\
(0.484)\end{array}$ & $\begin{array}{l}-0.387 \\
(0.510)\end{array}$ & $\begin{array}{l}-0.555 \\
(0.492)\end{array}$ \\
\hline $\begin{array}{l}\text { Relative military } \\
\text { capabilities }\end{array}$ & $\begin{array}{l}-0.056 \\
(0.101)\end{array}$ & $\begin{array}{c}0.018 \\
(0.107)\end{array}$ & $\begin{array}{l}-0.036 \\
(0.125)\end{array}$ & $\begin{array}{l}-0.053 \\
(0.117)\end{array}$ \\
\hline State target & $\begin{array}{l}-1.789^{*} \\
(0.719)\end{array}$ & $\begin{array}{c}-1.774 * * \\
(0.625)\end{array}$ & $\begin{array}{c}-2.275^{* *} \\
(0.796)\end{array}$ & $\begin{array}{c}-2.210 * * \\
(0.777)\end{array}$ \\
\hline Relative resolve & -- & $\begin{array}{l}-0.425 \\
(0.457)\end{array}$ & $\begin{array}{l}-0.763 \\
(0.570)\end{array}$ & $\begin{array}{l}-0.833 \\
(0.562)\end{array}$ \\
\hline Crisis & -- & $\begin{array}{l}1.190^{*} \\
(0.474)\end{array}$ & $\begin{array}{l}1.164^{*} \\
(0.488)\end{array}$ & $\begin{array}{l}1.048^{*} \\
(0.476)\end{array}$ \\
\hline Compliance PPO & -- & -- & $\begin{array}{c}-1.631^{* *} \\
(0.560)\end{array}$ & $\begin{array}{l}-0.578 \\
(0.682)\end{array}$ \\
\hline $\begin{array}{l}\text { Moderately } \\
\text { coercive PPO }\end{array}$ & -- & -- & $\begin{array}{l}-0.673 \\
(0.603)\end{array}$ & $\begin{array}{l}-0.589 \\
(0.597)\end{array}$ \\
\hline $\begin{array}{l}\text { Intervener } \\
\text { military power X } \\
\text { compliance PPO }\end{array}$ & -- & -- & -- & $\begin{array}{c}-12.239^{*} \\
(5.330)\end{array}$ \\
\hline Log likelihood & -169.923 & -164.760 & -159.174 & -157.260 \\
\hline$\chi^{2}$ statistic & $\begin{array}{c}32.26 \\
(p<0.001)\end{array}$ & $\begin{array}{c}49.93 \\
(p<0.001)\end{array}$ & $\begin{array}{c}59.06 \\
(p<0.001)\end{array}$ & $\begin{array}{c}65.08 \\
(p<0.001)\end{array}$ \\
\hline Observations & 174 & 174 & 174 & 174 \\
\hline
\end{tabular}

Robust standard errors in parentheses.

$\dagger$ significant at $p<0.10$; $*$ significant at $p<0.05$; ** significant at $p<0.01$; *** significant at $p<0.001$ 
Table II. Probability weak interveners use specific force level, by PPO type $P P O$ Force Level

\begin{tabular}{ccccc}
\hline $\mathbf{1}$ & $\mathbf{2}$ & $\mathbf{3}$ & $\mathbf{4}$ & $\mathbf{5}$ \\
\hline 0.04 & 0.02 & 0.11 & 0.05 & 0.78 \\
0.08 & 0.04 & 0.19 & 0.08 & 0.62 \\
& & & & \\
$-0.04,0.13$ & $-0.02,0.06$ & $-0.05,0.21$ & $-0.01,0.06$ & $-0.45,0.12$ \\
\hline
\end{tabular}

Table III. Probability strong interveners use specific force level, by PPO type $P P O$ Force Level

Territorial/ regime change

Compliance

$95 \%$ CI for $\Delta$ Probitis

\begin{tabular}{|c|c|c|c|c|c|}
\hline & & & & & \\
\hline & 1 & 2 & 3 & 4 & 5 \\
\hline $\begin{array}{l}\text { Territorial/ } \\
\text { regime change }\end{array}$ & 0.07 & 0.04 & 0.17 & 0.07 & 0.64 \\
\hline Compliance & 0.43 & 0.11 & 0.25 & 0.05 & 0.16 \\
\hline $95 \%$ CI for $\Delta$ & $0.10,0.62$ & $0.01,0.14$ & $-0.11,0.26$ & $-0.08,0.03$ & $-0.74,-0.24$ \\
\hline
\end{tabular}


Table IV. No force used during first days of intervention

\begin{tabular}{|c|c|c|c|c|}
\hline $\begin{array}{c}\text { DV: Escalation } \\
\text { Delay }\end{array}$ & $\begin{array}{c}\text { Model } 1.2 \\
(\text { No force day } 1)\end{array}$ & $\begin{array}{c}\text { Model } 2.2 \\
\text { (No force day 1) }\end{array}$ & $\begin{array}{c}\text { Model } 3.2 \\
\text { (No force first } \\
10 \text { davs) }\end{array}$ & $\begin{array}{c}\text { Model } 4.2 \\
\text { (No force first } 10 \\
\text { days) }\end{array}$ \\
\hline $\begin{array}{l}\text { Intervener military } \\
\text { power }\end{array}$ & $\begin{array}{c}10.170 * * * \\
(2.836)\end{array}$ & $\begin{array}{l}7.417 * * \\
(2.884)\end{array}$ & $\begin{array}{c}11.323^{* * * *} \\
(3.238)\end{array}$ & $\begin{array}{l}9.171^{* * *} \\
(3.195)\end{array}$ \\
\hline Coalition & $\begin{array}{l}-0.748 \\
(0.543)\end{array}$ & $\begin{array}{l}-0.938 \dagger \\
(0.556)\end{array}$ & $\begin{array}{l}-0.696 \\
(0.557)\end{array}$ & $\begin{array}{l}-0.803 \\
(0.594)\end{array}$ \\
\hline $\begin{array}{l}\text { Intervener } \\
\text { democracy }\end{array}$ & $\begin{array}{l}0.750 \dagger \\
(0.422)\end{array}$ & $\begin{array}{l}0.846 \dagger \\
(0.436)\end{array}$ & $\begin{array}{c}0.601 \\
(0.446)\end{array}$ & $\begin{array}{c}0.662 \\
(0.467)\end{array}$ \\
\hline Local ally & $\begin{array}{c}0.567 \\
(0.559)\end{array}$ & $\begin{array}{c}0.683 \\
(0.561)\end{array}$ & $\begin{array}{c}0.412 \\
(0.628)\end{array}$ & $\begin{array}{c}0.484 \\
(0.608)\end{array}$ \\
\hline $\begin{array}{l}\text { Military assistance } \\
\text { to target }\end{array}$ & $\begin{array}{c}0.331 \\
(0.549)\end{array}$ & $\begin{array}{c}0.520 \\
(0.534)\end{array}$ & $\begin{array}{c}0.684 \\
(0.596)\end{array}$ & $\begin{array}{c}0.831 \\
(0.583)\end{array}$ \\
\hline $\begin{array}{l}\text { Relative military } \\
\text { capabilities }\end{array}$ & $\begin{array}{c}0.071 \\
(0.099)\end{array}$ & $\begin{array}{c}0.097 \\
(0.101)\end{array}$ & $\begin{array}{c}0.115 \\
(0.120)\end{array}$ & $\begin{array}{c}0.137 \\
(0.118)\end{array}$ \\
\hline State target & $\begin{array}{l}1.732^{*} \\
(0.839)\end{array}$ & $\begin{array}{l}1.588 \dagger \\
(0.851)\end{array}$ & $\begin{array}{l}2.287^{*} \\
(0.982)\end{array}$ & $\begin{array}{l}2.191^{*} \\
(0.984)\end{array}$ \\
\hline Relative resolve & $\begin{array}{l}0.984 * \\
(0.435)\end{array}$ & $\begin{array}{l}1.107^{*} \\
(0.439)\end{array}$ & $\begin{array}{l}1.115^{*} \\
(0.533)\end{array}$ & $\begin{array}{l}1.229^{*} \\
(0.540)\end{array}$ \\
\hline Crisis & $\begin{array}{c}-0.823 \dagger \\
(.437)\end{array}$ & $\begin{array}{l}-0.644 \\
(0.436)\end{array}$ & $\begin{array}{c}-0.881 \dagger \\
(0.499)\end{array}$ & $\begin{array}{l}-0.734 \\
(0.501)\end{array}$ \\
\hline Compliance PPO & $\begin{array}{l}1.201^{*} \\
(0.556)\end{array}$ & $\begin{array}{l}-0.539 \\
(0.988)\end{array}$ & $\begin{array}{l}1.309^{*} \\
(0.607)\end{array}$ & $\begin{array}{c}0.062 \\
(1.232)\end{array}$ \\
\hline $\begin{array}{l}\text { Moderately } \\
\text { coercive PPO }\end{array}$ & $\begin{array}{l}-0.002 \\
(0.658) \\
\end{array}$ & $\begin{array}{l}-0.144 \\
(0.642)\end{array}$ & $\begin{array}{l}-0.109 \\
(0.705) \\
\end{array}$ & $\begin{array}{l}-0.165 \\
(0.680)\end{array}$ \\
\hline $\begin{array}{l}\text { Intervener military } \\
\text { power X } \\
\text { compliance PPO }\end{array}$ & -- & $\begin{array}{l}18.351^{*} \\
(8.381)\end{array}$ & -- & $\begin{array}{c}12.548 \\
(10.720)\end{array}$ \\
\hline Constant & $\begin{array}{c}-4.135^{* * * *} \\
(1.272)\end{array}$ & $\begin{array}{c}-4.111^{* * * *} \\
(1.282)\end{array}$ & $\begin{array}{c}-5.193^{* * * *} \\
(1.531)\end{array}$ & $\begin{array}{c}-5.197 * * * \\
(1.513)\end{array}$ \\
\hline Log likelihood & -76.918 & -74.708 & -65.252 & -64.278 \\
\hline$\chi^{2}$ statistic & $36.62(p<0.001)$ & $37.15(p<0.001)$ & $35.27(p<0.001)$ & $34.30(p<0.001)$ \\
\hline Observations & 174 & 174 & 174 & 174 \\
\hline
\end{tabular}

Robust standard errors in parentheses.

$\dagger$ significant at $p<0.10 ; *$ significant at $p<0.05 ; * *$ significant at $p<0.01 ; * * *$ significant at $p<0.001$ 
Table V. Change in predicted probability of delayed use of force

\begin{tabular}{|l|c|c|c|}
\hline Variable & $\Delta$ in power variable & $\begin{array}{c}\Delta \text { in probability } \\
\text { delay }\end{array}$ & CI for $\boldsymbol{\Delta}$ \\
\hline $\begin{array}{l}\text { Intervener military power, } \\
\text { non-compliance PPO }\end{array}$ & $\begin{array}{c}25^{\text {th }} \text { PCTL } \rightarrow 75^{\text {th }} \\
\text { PCTL }\end{array}$ & +0.16 & $0.03,0.28$ \\
\hline $\begin{array}{l}\text { Intervener military power, } \\
\text { compliance PPO }\end{array}$ & $\begin{array}{c}25^{\text {th }} \text { PCTL } \rightarrow 75^{\text {th }} \\
\text { PCTL }\end{array}$ & +0.64 & $0.38,0.90$ \\
\hline
\end{tabular}

Results from Model 2.2. Changes in the predicted probability of force delay are calculated when each dichotomous variable is held constant at modal value and each continuous variable is held constant at its mean. 25th percentile $=$ $0.018 ; 75$ th $=0.139$. 


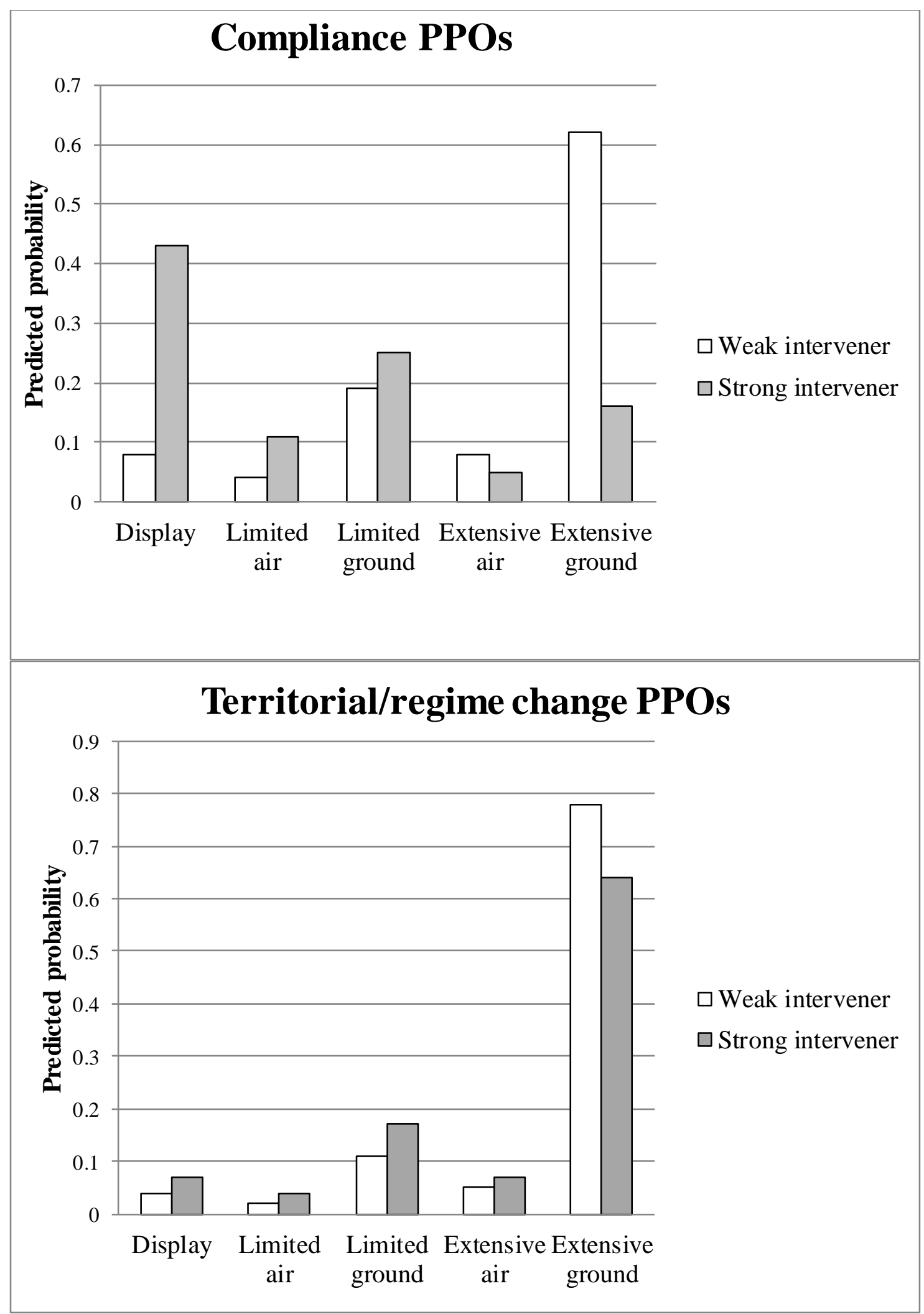

Figure 1. Use of force, compliance versus territorial/regime change PPOs 


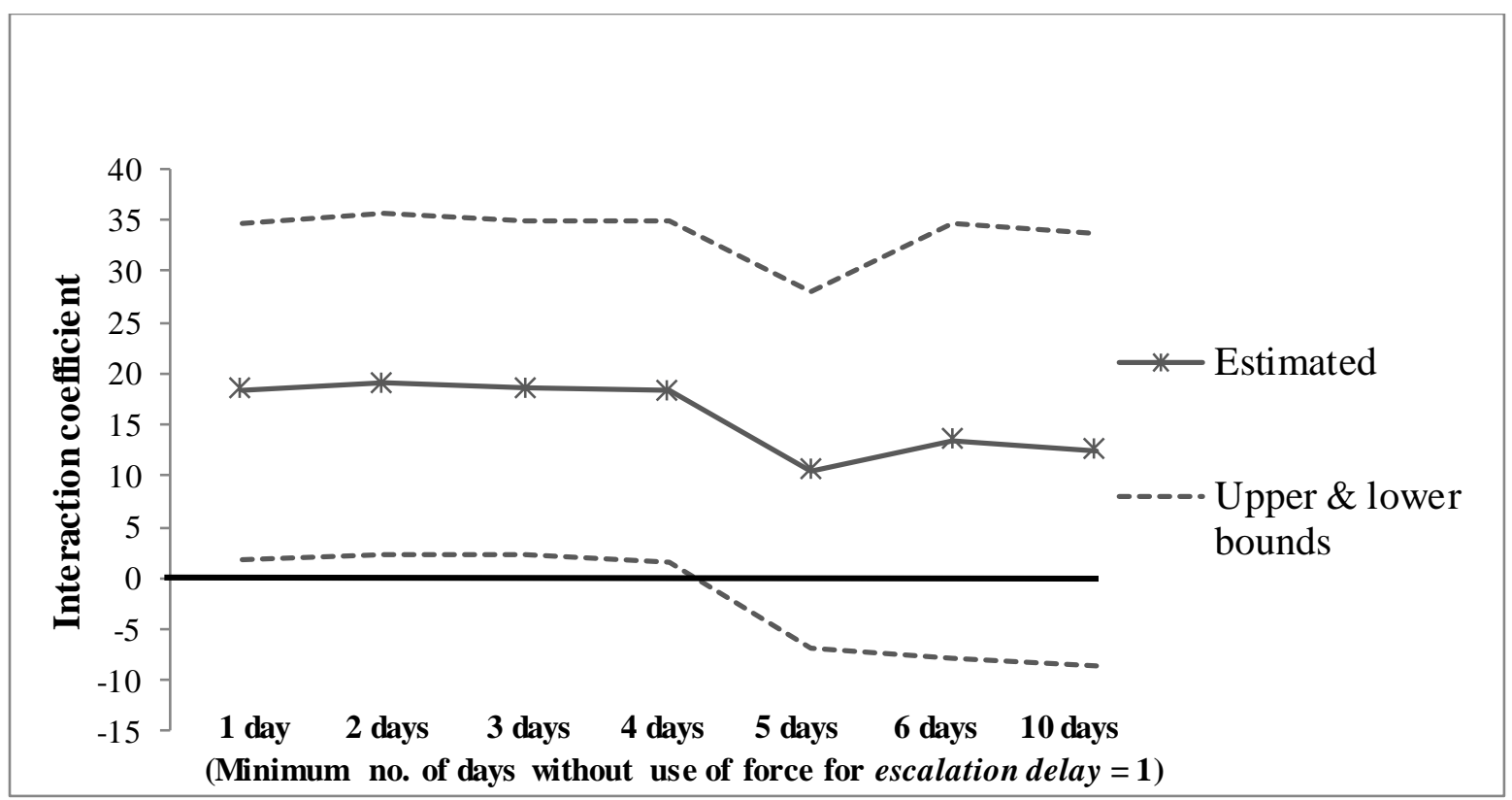

Figure 2. Interaction term (Model 2.2), by DV operationalization 